\title{
THIRTY-FOURTH CONGRESS OF FRENCH-SPEAKING ALIENISTS AND NEUROLOGISTS.
}

This Congress will be held at Lille from July 2 I to 26 , 1930, under the presidency of Prof. Abadie of Bordeaux.

1. Discussions will take place on the following subjects :

I. "The Cerebro-Spinal Fluid in Mental Disorders," to be opened by Dr. Lamache.

2. "Postural Reflexes," to be opened by Dr. Delmas-Marsalet.

3. "Social Insurance Law as applied to Patients with Mental Disorder," to be opened by Dr. Calmettes.

In addition numerous individual papers will be read, and various institutions will be visited.

The Secretary-General is Dr. P. Combemale, 93, rue d'Esquermes, Lille, from whom particulars as to membership may be obtained. The members' subscription will be $50 \mathrm{fr}$. (8s.). Reduced fares will be available on the French railways, and various tours will be organized after the meeting.

These congresses, although conducted exclusively in French, have a definitely international character. In view of the easy accessibility of Lille, it is hoped that there will be a good attendance of British visitors.

THE NATIONAL COMMITTEE FOR MENTAL HYGIENE, U.S.A.

The TWentieth AnNiversary.

The twentieth anniversary of the inauguration of the mental hygiene movement and the founding of the National Committee for Mental Hygiene was celebrated on Thursday evening, November 14, 1929, with a dinner at the Biltmore Hotel in New York City, attended by nearly 700 psychiatrists, psychologists, educationalists, social workers and prominent laymen from various parts of the country, and presided over by Dr. William H. Welch, Director of the Department of the History of Medicine of Johns Hopkins University and Honorary President of the National Committee.

Addresses were given by President James R. Angell, of Yale University, Dr. William A. White, Superintendent of St. Elizabeth's Hospital, Washington, and Dr. Frankwood E. Williams, Medical Director of the National Committee, all of whom paid tributes to Mr. Clifford W. Beers, author of $A$ Mind that Found Itself, the publication of which twenty-one years ago led to the organization of the National Committee.

Mr. Beers described the events incidental to the establishment in 1903, at the home of Anson Phelps Stokes, in New Haven, Connecticut, of the pioneer Connecticut Society for Mental Hygiene, from which the national movement grew, and reviewed the development of the work to the present time.

Dr. White, speaking of the aims and objects of the National Committee, said : “The average patient admitted to a State Hospital has already been getting mentally ill over a period of a number of years, sometimes throughout a lifetime of thirty or forty years, and it could not be expected that miracles of cure could be worked in this material, and so naturally those who were interested in mental hygiene began to ask themselves the questions: When does mental disease begin ? What are its earliest manifestations ? How can these manifestations be prevented ? And how can the prospective patient who is for the time being on the wrong track be gotten back in the right direction? And so over a considerable period of time we see movements calculated to attempt answers to these questions. We find psychiatrists at our instance being introduced in to the universities where they make contact with the adolescent youth of the country, and we find those same psychiatrists realizing that the adolescent who is headed for mental disease has been on 